\title{
Variables influencing ingestive behaviour of steers grazing Thinopyrum ponticum
}

\author{
G Santucho 1, C Cangiano 2, PO Gomez 2, H Fernandez 2 \\ 'EEA Anguil INTA ; 2 Unidad Integrada EEA Balcarce, INTA-Univ Nac M del Plata, Argentina
}

This study was carried out to detect pasture and/or animal variables influencing animal intake in different structures of Thinopyrum ponticum (Podp) Barkw. \& Dewey (ex Agropyron elongatum (Host) Beauv), at EEA Balcarce, INTA, Argentina.

The experiment was carried out on a paddock of $18 \mathrm{ha}$, in three experimental periods with different pasture structures : T1 : initial herbage mass of $1500 \mathrm{~kg} \mathrm{MO} / \mathrm{ha}$, lamina $56 \%$ and dead material $30 \%$; $\mathrm{T} 2$ : initial herbage mass of more than $2500 \mathrm{~kg} \mathrm{MO} / \mathrm{ha}, 26 \%$ of elongated stems in the pasture, lamina $44 \%$ and dead material $30 \% ; \mathrm{T} 3$ : initial herbage mass of more than $3500 \mathrm{~kg} \mathrm{MO} / \mathrm{ha}$, stems $42 \%$, lamina $28 \%$ and dead material $28 \%$. Three replications of each structure were grazed during 10 days. Data were collected at intervals of two days. Fifteen 14-month-old steers, 8 of them fitted with oesophageal fistula, were used. Forty nine variables were measured in order to characterize the pasture structure, 7 variables to characterize eating behaviour and 9 variables the diet selected by the animals. Simple correlations between all variables were obtained and canonical correlation were performed for the 3 pasture structures.

Relative availability of lamina, lamina : sheath + stem and dead material proportions, neutral detergent fibre of stems were selected by canonical correlation analysis, as important variables among those characterizing pasture structure. Among diet components, leaf, stem and dead material proportions were selected, and bite weight, eating bites and grazing time among ingestive behaviour variables. In $T_{1}$ canonical correlations between pasture and diet variables were : $r_{\mathrm{ca}}$ (adjusted canonical coefficient) $=0.87, P>F: 0.25$ and $R^{2}=0.82$, and between diet and ingestive behaviour variables, $r_{c a}=0.58, P>F: 0.33$ and $R^{2}=0.48$. The last ones were well correlated with pasture variables $\left(r_{c a}=0.80, P>F: 0.33\right.$ and $\left.R^{2}=0.74\right)$. The same type of correlations was found in T2 : between pasture and diet canonical variables, $r_{\text {ca }}=0.89, P>F: 0.04$ and $R^{2}=0.85$; between pasture and ingestive behaviour, $r_{c a}=0.66$, P>F : $0.19 ; \mathrm{R}^{2}=0.56$. In T3 the highest correlations were between pasture and diet variables $\left(r_{c a}=0.93, P>F: 0.04\right.$ and $\left.R^{2}=0.90\right)$, and between the last ones and ingestive behaviour variables $\left(r_{c a}=0.83, P>F: 0.02\right.$ and $\left.R^{2}=0.75\right)$. The relation between pasture and ingestive behaviour variables was : $r_{c a}=0.76$, $P>F: 0.13$ and $R^{2}=0.71$.

Intake was limited by structural characteristics from pasture. The results showed that relative availability of lamina and lamina : sheath + stem ratio are biological indicators of diet selection and to a lesser extent of ingestive behaviour. 